\title{
Is ketamine a lifesaving agent in childhood acute severe asthma?
}

\author{
This article was published in the following Dove Press journal: \\ Therapeutics and Clinical Risk Management \\ 22 February 2016 \\ Number of times this article has been viewed
}

\author{
Mohamed A Hendaus ${ }^{1,2}$ \\ Fatima A Jomha ${ }^{3}$ \\ Ahmed H Alhammadi ${ }^{1,2}$ \\ 'Department of Pediatrics, Section \\ of Academic General Pediatrics, \\ Hamad Medical Corporation, Doha, \\ ${ }^{2}$ Department of Clinical Pediatrics, \\ Weill Cornell Medical College in \\ Qatar, Doha, Qatar; ${ }^{3}$ School of \\ Pharmacy, Lebanese International \\ University, Khiara, Lebanon
}

\begin{abstract}
Children with acute severe asthma exacerbation are at risk of developing respiratory failure. Moreover, conventional aggressive management might be futile in acute severe asthma requiring intubation and invasive ventilation. The aim of this review is to detail evidence on the use of ketamine in childhood asthma exacerbations. A search of the MEDLINE, EMBASE, and Cochrane databases was performed, using different combinations of the following terms: ketamine, asthma, use, exacerbation, and childhood. In addition, we searched the references of the identified articles for additional articles. We then reviewed titles and included studies that were relevant to the topic of interest. Finally, the search was limited to studies published in English and Spanish from 1918 to June 2015. Due to the scarcity in the literature, we included all published articles. The literature reports conflicting results of ketamine use for acute severe asthma in children. Taking into consideration the relatively good safety profile of the drug, ketamine might be a reasonable option in the management of acute severe asthma in children who fail to respond to standard therapy. Furthermore, pediatricians and pediatric emergency clinicians administering ketamine should be knowledgeable about the unique actions of this drug and its potential side effects.
\end{abstract}

Keywords: asthma, ketamine, children

\section{Introduction}

The Global Strategy for Asthma Management and Prevention Guidelines describes asthma as a chronic inflammatory disorder of the airways associated with increased airway hyperresponsiveness, recurrent episodes of wheezing, breathlessness, chest tightness, and coughing, particularly at night/early morning. ${ }^{1}$ Moreover, asthma is classified as one of the most common chronic diseases in children. ${ }^{2}$ Acute severe asthma, previously referred to as status asthmaticus, is a phenomenon in which asthmatics do not respond to bronchodilators and corticosteroids, ${ }^{3}$ and it comprises $\sim 500,000$ yearly admissions to the pediatric intensive care unit (PICU). ${ }^{46}$ In the USA, asthma affects $>7$ million children, of which 4 million experience at least one attack of asthma exacerbation. ${ }^{7}$ Fortunately, the prevalence of asthma attacks is not on the rise. This might be attributed to the dissemination of national asthma guidelines that emphasize on preventive measures. ${ }^{7-9}$ The prevalence of asthma in children is $9.6 \%$ compared to $7.7 \%$ in adults. Moreover, children who live below poverty level have higher prevalence of asthma compared to children who belong to families with a higher socioeconomic status. ${ }^{7}$ The reported prevalence of asthma deaths for children and adults younger than 35 years was 3.4 per million in 2007. In addition, children with asthma missed 10.5 million school days in 2008 due to their disease. ${ }^{?}$

Children with acute severe asthma exacerbations are at risk of developing respiratory failure, and conventional aggressive management might be futile requiring
Correspondence: Mohamed A Hendaus Hamad Medical Corporation, Weill

Cornell Medical College, Doha 3050, Qatar

Emailmhendaus@yahoo.com
Therapeutics and Clinical Risk Management 2016:12 273-279

Dovepress

http://dx.doi.org/10.2147/TCRM.S100389

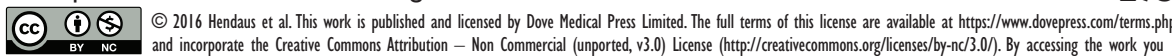
hereby accept the Terms. Non-commercial uses of the work are permitted without any further permission from Dove Medical Press Limited, provided the work is properly attributed. For permisision

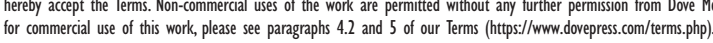


intubation and invasive ventilation. ${ }^{10,11}$ Ketamine has been described as a sedative for intubation and invasive ventilation in children with severe asthma attacks. ${ }^{12}$ It provides stability to airway reflexes and cardiac performance while simultaneously inducing amnesia, analgesia, and decline in airway resistance. ${ }^{13}$ Moreover, ketamine might be useful in managing severe asthma attacks in children when conventional management fails. ${ }^{13,14}$ In this review, we discuss the effectiveness and safety of ketamine in children with refractory asthma attacks.

The aim of this review is to detail evidence on the use of ketamine in childhood asthma exacerbations.

\section{Methods}

We carried out a search of the MEDLINE, EMBASE, and Cochrane databases, using different combinations of the following terms: ketamine, asthma, use, exacerbation, and childhood. In addition, we searched the references of the identified articles for additional articles. We then reviewed the abstracts and titles and included studies that were relevant to the topic of interest. Finally, the search was limited to studies published in English and Spanish from 1918 to June 2015. Outcome measures were analyzed using the following clinical findings: evidence, dose and duration of ketamine use, safety, secondary effects, and mortality. Due to the scarcity in the literature, we included all published articles (randomized control trials, reviews, case reports, retrospective studies, and Cochrane). The literature reports conflicting results of ketamine use for acute severe asthma in children.

\section{Discussion}

\section{Ketamine}

Ketamine is a drug mainly used for the induction and maintenance of anesthesia. It has also been used for the induction of sedation, as a pain killer, as an antidepressant, for the management of bronchospasm, and as a treatment for complex regional pain syndrome. One of the advantages of ketamine is that breathing, heart function, and, according to some authors, airway reflexes stay functional during the drug infusion. ${ }^{13}$ It is an excellent choice of sedative for children requiring rapid sequence intubation for life-threatening asthma. ${ }^{14-18}$ In 1962, the World Health Organization ${ }^{19,20}$ listed ketamine as an essential medicine. Ketamine, previously known as CI581, is a water-soluble agent, noncompetitive $N$-methyl-D-aspartate (NMDA) receptor antagonist, a derivative of phencyclidine, and it has two enantiomers, $S(+)$ ketamine and $R(-)$-ketamine. ${ }^{21,22}$ Commercially available ketamine is marketed as a racemic mixture comprising equal amounts of $(S)$ - and $(R)$-ketamine. The D-S(-) isomer of ketamine has three- to fourfold the potency and fivefold better affinity to NMDA when compared to the $\mathrm{L}-R(-)$ isomer. ${ }^{21}$ Intramuscular and intravenous ketamine has a high bioavailability with a half-life of 2-3 hours and a rapid onset of action reaching peak plasma concentration in 60 seconds. Moreover, it has a short duration of action (10-15 minutes after a single bolus injection). ${ }^{22,23}$ On the other hand, oral ketamine has a low (up to $20 \%$ ) bioavailability, tardy absorption, and slow peak ratio. ${ }^{24-26}$

In addition to being an NMDA receptor antagonist, ketamine also acts on opioid receptors and monoamine transporters. Moreover, ketamine is a dissociative agent, ${ }^{27,28}$ that is, absorbable by intravenous, intramuscular, oral, and topical routes due to both its hydrophilic and lipophilic characteristics. ${ }^{29}$ It undergoes first-pass metabolism and is metabolized in the liver by CYP3A4 (major), CYP2B6 (minor), and CYP2C9 (minor) isoenzymes mainly into norketamine (through N-demethylation) and dehydronorketamine. ${ }^{26}$ Dehydronorketamine and norketamine are the two most common metabolites detected in urine. ${ }^{30}$ Benzodiazepines such as diazepam and other CYP3A4 inhibitors can potentially increase plasma concentrations of ketamine. ${ }^{25}$ In addition, other commonly used medications in pediatric medicine such as epinephrine, doxapram, fentanyl, isocarboxazid, phenelzine, and magnesium sulfate can interact with ketamine. $^{31,32}$

\section{Mechanism of action of ketamine as an airway relaxant and bronchodilator}

The proposed mechanisms of airway relaxation contain ketamine inhibition of postsynaptic nicotinic or muscarinic receptors, voltage-sensitive $\mathrm{Ca}^{2+}$ channel blockage, induced inhibition of catecholamine reuptake, and increased catecholamine concentrations. ${ }^{10,33}$ Moreover, other suggested mechanisms of airway relaxation include suppression of macrophage function of phagocytosis, its oxidative ability, and inflammatory cytokine production. ${ }^{34}$ Ketamine bolsters bronchorrhea and bronchodilation assisting in the clearance of mucus plugs. ${ }^{35}$ It also functions as a bronchodilator when administered in low dose. ${ }^{36}$ Moreover, it has also been proven that ketamine at sedative doses is effective in the management of severe asthma attacks averting the need for endotracheal intubation. ${ }^{14-16}$ Investigations conducted on murine models showed that ketamine has protective effects on high airway reactivity in asthma and on allergen-triggered airway inflammation. ${ }^{37}$ 
In a different murine study, Zhu et al ${ }^{38}$ evaluated the effect of ketamine inhalation on bronchial hyperresponsiveness and airway inflammation in a brown Norway rat model of ovalbumin-induced allergic asthma. The study concluded that ketamine in a nebulized form using an ultrasonic nebulizer significantly reduced airway inflammation, allergen-mediated airway hyperreactivity, and airway inflammatory cell infiltration into the bronchoalveolar lavage fluid. Moreover, the authors noted marked suppression of interleukin-4 in the bronchoalveolar lavage fluid and expression of inducible nitric oxide synthase and the concentration of nitric oxide in the inflamed airways from ovalbumin-treated rats. Moreover, ketamine relaxes and decreases bronchomotor tone perhaps due to interference with a $\mathrm{Ca}^{2+}$ crucial step necessary to maintain the contraction caused by histamine. ${ }^{39,40}$ Ketamine has been successfully used in patients with severe bronchospasm who do not respond to traditional management, such as $\beta_{2}$-agonists, corticosteroids, and anticholinergics..$^{10,15,41}$ Moreover, the same studies have shown that administration of ketamine is beneficial in ventilated and in nonventilated pediatric patients with acute asthma exacerbation. ${ }^{10,15,41}$

\section{Effect of ketamine on respiration}

The impact of ketamine on respiration varies, and the literature lacks homogeneity with regard to this issue. Bourke et $\mathrm{al}^{42}$ concluded that ketamine, in low dose, depresses ventilation but has no influence on the respiratory response to increasing levels of carbon dioxide. However, Hamza et $\mathrm{a}^{43}$ found that ketamine is a respiratory depressant, particularly after an intravenous bolus dose, and it reduces the responsiveness of respiratory center to $\mathrm{CO}_{2}$. Moreover, Shulman et $\mathrm{al}^{44}$ mentioned that the use of ketamine does not alter functional residual capacity and minute ventilation in children.

\section{Ketamine in acute severe asthma}

Ketamine was initially synthesized in 1962 by Calvin Stevens, and the Federal Drug Administration agency eventually approved the use of ketamine as an anesthetic agent in 1970. ${ }^{19,45}$ In 1971, Betts and Parkin ${ }^{46}$ described complete resolution of wheezing in a preschooler with severe asthma after the administration of ketamine. The dose of ketamine initially used was $75 \mathrm{mg} / \mathrm{kg}$ intramuscularly, followed by $10 \mathrm{mg}$ of administered intravenously approximately every 15 minutes adding up to a total of $115 \mathrm{mg}$. In 1972, Corssen et $\mathrm{al}^{47}$ monitored the effect of ketamine use in 44 asthmatic children and adults. The induction dose of ketamine (1\%) used was
$1-2 \mathrm{mg} / \mathrm{kg}$ intravenously and $0.5-1 \mathrm{mg} / \mathrm{kg}$ at $15-30$ minutes intervals for maintenance. The study concluded that ketamine protects against exacerbation of asthma, improves acute bronchospasm when administered with other anesthetic agents, and ameliorates bronchospasm in children and adults with respiratory distress. In 1986, Strube and Hallam ${ }^{48}$ reported about a 13-year-old girl who was admitted to the PICU with status asthmaticus and failed to respond to conventional bronchodilator therapy to relieve her bronchospasm. The dose of ketamine used was $40 \mu \mathrm{g} / \mathrm{kg} / \mathrm{min}$ for a period of 8 hours. The patient significantly improved after the ketamine infusion and obviated the need for intubation and mechanical ventilation. In 1992, Sarma ${ }^{49}$ presented two patients with acute severe asthma who did not respond to standard therapy. Ketamine was used as a bolus dose of $0.75 \mathrm{mg} / \mathrm{kg}$, followed by the same dose over 10 minutes, resulting in amelioration of bronchospasm. In 1993, Jahangir et $\mathrm{al}^{50}$ conducted a cohort study to assess the benefits of providing complete postoperative analgesia in asthmatics with ketamine delivered in subanesthetic doses $(6.10-6.41 \mu \mathrm{g} / \mathrm{kg} / \mathrm{min})$. The study concluded that respiratory functions were favorable for asthmatics. Complications of ketamine were reported as minimal. In 1994, Hemmingsen et $\mathrm{al}^{51}$ evaluated ketamine in the treatment of bronchospasm during mechanical ventilation via a prospective, placebo-controlled, double-blinded trial. Fourteen mechanically ventilated patients with bronchospasm were randomly selected to receive either ketamine $1 \mathrm{mg} / \mathrm{kg}$ or saline placebo. The study concluded that the ketamine-treated patients showed an improvement in air entry, in $\mathrm{PO}_{2}$ and in $\mathrm{PCO}_{2}$, indicating that ketamine might be effective in the treatment of bronchospasm during mechanical ventilation. In 1996, Youssef-Ahmed et $\mathrm{al}^{52}$ researched the continuous infusion of ketamine in mechanically ventilated children with refractory bronchospasm in 17 infants and children who were admitted to the PICU. The ketamine dose was $2 \mathrm{mg} / \mathrm{kg}$ as an IV bolus, followed by continuous infusions of $20-60 \mu \mathrm{g} / \mathrm{kg} / \mathrm{min}$. The authors concluded that continuous infusion of ketamine ( $40 \pm 31$ hours) to mechanically ventilated patients with refractory bronchospasm markedly improved the dynamic compliance of the chest and gas exchange. In 2001, Petrillo et al ${ }^{15}$ conducted a prospective observational study to assess the effects of adding ketamine to standard emergency department therapy for patients with status asthmaticus. The study included ten children who did not respond to conventional therapy. The ketamine dose used was $1 \mathrm{mg} / \mathrm{kg}$ intravenously for the loading dose, followed by a continuous infusion of $0.75 \mathrm{mg} / \mathrm{kg} / \mathrm{h}(12.5 \mu \mathrm{g} / \mathrm{kg} / \mathrm{min})$ for 1 hour. The authors concluded that there was a significant 
reduction in clinical asthma scores by $37 \%$. In addition, the median respiratory rate and oxygen requirement improved, but the peak expiratory flow (PEF) did not show significant improvement. Forty percent of the children involved in the study experienced minor side effects, such as diffuse flushing, moderate increase in blood pressure, and mild hallucinations. In 2003 , Heshmati et $\mathrm{al}^{41}$ conducted a prospective observational study to evaluate the use of ketamine in severe status asthmaticus in the intensive care unit. Ketamine was administered to eleven patients (aged 15-40 years old) with status asthmaticus in respiratory failure. The received ketamine dose was $1 \mathrm{mg} / \mathrm{kg}$ intravenously as a loading dose, followed by a continuous infusion of $1 \mathrm{mg} / \mathrm{kg} / \mathrm{h}$ for 2 hours. Peak airway pressures, $\mathrm{PaCO}_{2}$ and $\mathrm{PaO}_{2}$, were monitored prior to ketamine administration, 15 minutes after administration, and 2 hours after infusion of ketamine. The authors concluded that the mean peak airway pressure and $\mathrm{PaCO}_{2}$ declined significantly $(P<0.005)$ and $\mathrm{PaO}_{2}$ raised significantly $(P<0.005)$ after 15 minutes and 2 hours of ketamine infusion. In 2006, Denmark et $\mathrm{al}^{14}$ published two cases of severe asthma exacerbations in prepubertal children. The authors concluded that the administration of a bolus of intravenous ketamine followed by a continuous infusion of a relatively large dose of ketamine resulted in prompt improvement, averting the need for mechanical ventilation. In 2008, Shlamovitz and Hawthorne ${ }^{16}$ presented a case of severe asthma exacerbation who did not respond to conventional therapy. The authors concluded that the patient improved dramatically after the administration of intravenous ketamine $(0.75 \mathrm{mg} / \mathrm{kg}$ intravenous bolus followed by continuous drip of $0.15 \mathrm{mg} / \mathrm{kg} / \mathrm{h}$ ). In 2012, Jat el $\mathrm{al}^{53}$ reported a case of a 2-month-old male who presented with respiratory distress. The patient did not respond to oxygen supplementation, adrenaline nebulization, salbutamol nebulization, oral prednisolone, ipratropium nebulization, intravenous hydrocortisone, terbutaline infusion, magnesium sulfate, and aminophylline. Intravenous ketamine was used as $1 \mathrm{mg} / \mathrm{kg}$ bolus followed by continuous infusion at the rate of $10 \mu \mathrm{g} / \mathrm{kg} / \mathrm{min}$. The ketamine infusion rate was eventually increased to $15 \mu \mathrm{g} / \mathrm{kg} / \mathrm{min}$. With the administration of ketamine, oxygen saturation improved and wheezing and respiratory distress decreased. Terbutaline, aminophylline and ketamine were weaned off in 48 hours. In 2014, Agrawal and Shrivastava ${ }^{54}$ published a case of a 2 -year-old female who presented with respiratory failure due to severe bronchospasm. The child who was found to be H1N1 positive did not respond to ipratropium and budesonide nebulization, intravenous hydrocortisone, magnesium sulfate, subcutaneous adrenaline, and intravenous infusion of terbutaline and aminophylline. Ketamine was eventually administered as initial bolus $(0.5 \mathrm{mg} / \mathrm{kg})$ followed by continuous infusion $(0.5 \mathrm{mg} / \mathrm{kg} / \mathrm{h})$ and increased gradually up to $2 \mathrm{mg} / \mathrm{kg} / \mathrm{h}$. The child showed improvement in peak inspiratory pressure, gas exchange, and $\mathrm{SpO}_{2}$ and decrease in wheezing within a 4-hour period. The magnesium, aminophylline, and terbutaline infusions were weaned off gradually in 24 hours.

On the other hand, other studies showed that the infusion of ketamine does not provide benefits over the conventional therapy in children with moderate-to-severe asthma exacerbation. For instance, Allen and Macias ${ }^{36}$ conducted a doubleblinded, randomized, placebo-controlled trial to evaluate children aged 2-18 years old who presented to a pediatric emergency department with an acute asthma exacerbation. Sixty-eight children met the criteria: 33 children were randomized to receive ketamine infusion and 35 children received normal saline. Exclusion criteria included focal infiltrate on radiograph, fever $>39^{\circ} \mathrm{C}\left(102^{\circ} \mathrm{F}\right)$, or any glucocorticoid use in the last 72 hours. All children received three treatments with albuterol, ipratropium bromide, and a dose of oral or parenteral glucocorticoids. The group of children randomized to receive ketamine were administered an intravenous bolus of $0.2 \mathrm{mg} / \mathrm{kg}$ of ketamine, followed by a 2-hour ketamine infusion at $0.5 \mathrm{mg} / \mathrm{kg} / \mathrm{h}$. The study showed that the mean decrease in the pulmonary index scores at the end of the infusion was $3.2 \pm 2.0$ in the ketamine group versus $3.6 \pm 1.3$ in the placebo group (difference of mean 0.4 ; 95\% confidence interval [CI] -0.4 to 1.3$)$. There were no reported short-term adverse effects. Moreover, Howton et $\mathrm{al}^{55}$ carried out a prospective, randomized, double-blinded, placebo-controlled trial to evaluate the efficacy of ketamine as a bronchodilator in acute severe asthma. The study included 53 patients aged between 18 years and 65 years with acute asthma exacerbation and PEF $<40 \%$ after three doses of albuterol nebulization. Methylprednisolone, oxygen, and continuous nebulized albuterol were provided to all the patients. Thereafter, all patients received either ketamine $0.2 \mathrm{mg} / \mathrm{kg}$ bolus, followed by a continuous intravenous infusion at $0.5 \mathrm{mg} / \mathrm{kg} / \mathrm{h}$ for 3 hours, or a placebo bolus and infusion for the same duration. The bolus dose of ketamine was eventually decreased to $0.1 \mathrm{mg} / \mathrm{kg}$ due to dysphoric reactions in some patients. There was statistically and clinically marked improvement in forced expiratory volume at the end of the first second, PEF, Borg score, and respiratory rate within each group. However, there was no significant difference in outcome between both groups (power, $80 \%$ ). The authors concluded that there was no increased bronchodilator effect compared with conventional therapy in treating acute severe asthma in the emergency department. 
Furthermore, Jat and Chawla ${ }^{56}$ conducted a Cochrane study to assess the efficacy of ketamine compared to placebo and reported that there was no intervention or standard care for the management of acute severe asthma in children who had failed standard therapy. RCTs comparing ketamine to placebo or conventional management in children with acute asthma exacerbation who failed conventional therapy were included in the study. Only one study was found eligible for inclusion. The authors reported no significant difference in oxygen saturation, respiratory rate, hospital admission rate, and the need for endotracheal intubation between the ketamine group $(0.2 \mathrm{mg} / \mathrm{kg}$ intravenous bolus over 1-2 minutes, followed by a $0.5 \mathrm{mg} / \mathrm{kg} / \mathrm{h}$ continuous infusion for 2 hours) and the placebo group.

\section{Side effects of ketamine}

Ketamine must be used with discretion, since unwanted effects include hypoventilation, hypertension, laryngospasm, and emergence agitation. ${ }^{35}$ When given intravenously, ketamine must be given slowly to prevent transient respiratory depression and laryngospasm. ${ }^{57}$ Ketamine must be used with caution in patients with seizure disorders, since it may decrease the seizure threshold. ${ }^{58}$ Moreover, ketamine increases cerebral blood flow, which may intensify intracranial and intraocular pressures. ${ }^{59}$ Undesirable recovery reactions, including atrial fibrillation and agitation, have been well documented in the adult literature. ${ }^{33,60}$ However, the literature states that the side effects of ketamine are uncommon in children and teenagers, and they are typically mild. ${ }^{34,61,62}$ Ketamine administered as a bolus dose ranging from $0.1 \mathrm{mg} / \mathrm{kg}$ to $2 \mathrm{mg} / \mathrm{kg}$ followed by continuous infusion $(0.15-2.5 \mathrm{mg} / \mathrm{kg} / \mathrm{h})$ displays no major adverse effects. The minor side effects reported include hallucinations, dysphoria, mild disruptions in heart rate and blood pressure in few patients, and increased secretions. ${ }^{10,31}$

\section{Ketamine neurotoxicity}

There have been serious concerns on the possible detrimental neurotoxic side effects of exposures to ketamine in children, such as brain neuronal destruction and eventually learning disability. ${ }^{63-65}$ In 1999 , Ikonomidou et al ${ }^{66}$ have suggested that ketamine and its derivatives might lead to brain cells' apoptosis, especially during the active brain development in immature animals. Other studies also showed that the administration of several doses of ketamine to neonatal rats might result in brain apoptosis. ${ }^{67,68}$ Braun et $\mathrm{al}^{69}$ studied the mechanism of cytotoxicity in different human neuronal cells and lymphocytes in vitro. The investigation concluded that ketamine at millimolar concentrations can trigger apoptosis through the mitochondrial pathway and not mediated through the NMDA receptor. Finally, clinical findings support that cognitive disorders may ensue ketamine chronic use ${ }^{70}$ but rarely reported with acute use. ${ }^{71}$

\section{Conclusion}

Ketamine is a good choice of sedative for children requiring rapid sequence intubation for life-threatening asthma. However, the literature reports conflicting results of its use in acute severe asthma in children. Taking into consideration the relatively good safety profile of the drug, ketamine might be a reasonable option in the management of acute severe asthma in children who fail to respond to standard therapy. Pediatricians and pediatric emergency clinicians administering ketamine should be knowledgeable about the unique actions of this drug and its potential side effects. Moreover, larger randomized controlled trials are required to better study the efficacy of ketamine in the management of acute severe asthma in children.

\section{Disclosure}

The authors report no conflicts of interest in this work.

\section{References}

1. GINA [webpage on the Internet]. Global Strategy for Asthma Management and Prevention. Available from: http://www.ginasthma.org/pdf/ GINA-Pocket-2010a.pdf. Accessed February 26, 2015.

2. Rust G, Zhang S, Reynolds J. Inhaled corticosteroid adherence and emergency department utilization among Medicaid-enrolled children with asthma. J Asthma. 2013;50:769-775.

3. Kaza V, Bandi V, Guntupalli KK. Acute severe asthma: recent advances. Curr Opin Pulm Med. 2007;13(1):1-7.

4. Kelly CS, Andersen CL, Pestian J, et al. Improved outcomes for hospitalized asthmatic children using a clinical pathway. Ann Allergy Asthma Immunol. 2000;84:509-516.

5. Birken CS, Parkin PC, Macarthur C. Asthma severity scores for preschoolers displayed weaknesses in reliability, validity, and responsiveness. J Clin Epidemiol. 2004;57:1177-1181.

6. Mannino DM, Homa DM, Akinbami LJ, Moorman JE, Gwynn C, Redd SC. Surveillance for asthma - United States, 1980-1999. MMWR Surveill Summ. 2002;51:1-13.

7. Akinbami LJ, Moorman JE, Liu X. Asthma prevalence, health care use, and mortality: United States, 2005-2009. Natl Health Stat Report. 2011;32:1-14.

8. Akinbami LJ, Schoendorf KC, Parker J. US childhood asthma prevalence estimates: the impact of the 1997 National Health Interview Survey redesign. Am J Epidemiol. 2003;158:99-104.

9. Akinbami L. The state of childhood asthma, United States, 1980-2005. Adv Data. 2006;381:1-24.

10. Werner HA. Status asthmaticus in children: a review. Chest. 2001; 119:1913-1929.

11. Sly RM. Decreases in Hispanic and non-Hispanic asthma mortality. Ann Allergy Asthma Immunol. 2006;96:76-79. 
12. Maddox RP, Seupaul RA. Is ketamine effective for the management of acute asthma exacerbations in children? Ann Emerg Med. 2014; 63:309-310.

13. Green SM, Roback MG, Kennedy RM, Krauss B. Clinical practice guideline for emergency department ketamine dissociative sedation: 2011 update. Ann Emerg Med. 2011;57:449-461.

14. Denmark TK, Crane HA, Brown L. Ketamine to avoid mechanical ventilation in severe pediatric asthma. J Emerg Med. 2006;30: 163-166.

15. Petrillo TM, Fortenberry JD, Linger JF, Simon HK. Emergency department use of ketamine in pediatric status asthmaticus. J Asthma. 2001;38:657-664

16. Shlamovitz GZ, Hawthorne T. Intravenous ketamine in a dissociating dose as a temporizing measure to avoid mechanical ventilation in adult patient with severe asthma exacerbation. J Emerg Med. 2011;41: 492-494.

17. L'Hommedieu CS, Arens JJ. The use of ketamine for the emergency intubation of patients with status asthmaticus. Ann Emerg Med. 1987; 16:568-571.

18. Rock MJ, Reyes de la Rocha S, L'Hommedieu CS, Truemper E. Use of ketamine in asthmatic children to treat respiratory failure refractory to conventional therapy. Crit Care Med. 1986;14:514-516.

19. Ketamine [webpage on the Internet]. Center for Substance Abuse Research (CESAR). University of Maryland. Available from: http:// www.cesar.umd.edu/cesar/drugs/ketamine.asp. Accessed December 25, 2014.

20. WHO. WHO Model List of Essential Medicines. 18th ed. Geneva: World Health Organization; 2013.

21. Li Y, Coller JK, Hutchinson MR, et al. The CYP2B6*6 allele significantly alters the N-demethylation of ketamine enantiomers in vitro. Drug Metab Dispos. 2013;41:1264-1272.

22. Stevenson C. Ketamine: a review. Update Anaesth. 2005;20:25-29.

23. Reich DL, Silvay G. Ketamine: an update on the first twenty-five years of clinical experience. Can J Anaesth. 1989;36:186-197.

24. Brunette KE, Anderson BJ, Thomas J, Wiesner L, Herd DW, Schulein S. Exploring the pharmacokinetics of oral ketamine in children undergoing burns procedures. Paediatr Anaesth. 2011;21:653-662.

25. Quibell R, Prommer EE, Mihalyo M, Twycross R, Wilcock A. Ketamine. J Pain Symptom Manage. 2011;41:640-649.

26. Sinner B, Graf BM. Ketamine. In: Schüttler J, Schwilden H, editors. Modern Anesthetics. Handbook of Experimental Pharmacology. Vol. 182. Berlin: Springer; 2008:313-333.

27. Kohrs R, Durieux ME. Ketamine: teaching an old drug new tricks. Anesth Analg. 1998;87:1186-1193.

28. Bergman SA. Ketamine: review of its pharmacology and its use in pediatric anesthesia. Anesth Prog. 1999;46:10-20.

29. Aroni F, Iacovidou N, Dontas I, Pourzitaki C, Xanthos T. Pharmacological aspects and potential new clinical applications of ketamine: reevaluation of an old drug. J Clin Pharmacol. 2009;49:957-964.

30. Li JH, Vicknasingam B, Cheung YW, et al. To use or not to use: an update on licit and illicit ketamine use. Subst Abuse Rehabil. 2011;16:11-20.

31. Ketamine [webpage on the Internet]. Medscape. Available from: http:// reference.medscape.com/drug/ketalar-ketamine-343099\#3. Accessed December 7, 2015.

32. Ketamine [webpage on the Internet]. Basow DS, editor. Waltham, MA: UpToDate. Available from: http:/www.uptodate.com/contents/ ketamine-pediatric-drug-information?source=search_result\&search= ketamine\&selectedTitle $=2 \sim 148 \#$ F185702. Accessed December 8, 2015.

33. Goyal S, Agrawal A. Ketamine in status asthmaticus: a review. Indian J Crit Care Med. 2013;17:154-161.

34. Chang Y, Chen TL, Sheu JR, Chen RM. Suppressive effects of ketamine on macrophage functions. Toxicol Appl Pharmacol. 2005;204:27-35.

35. White PF, Way WL, Trevor AJ. Ketamine - its pharmacology and therapeutic uses. Anesthesiology. 1982;56:119-136.

36. Allen JY, Macias CG. The efficacy of ketamine in pediatric emergency department patients who present with acute severe asthma. Ann Emerg Med. 2005;46:43-50.
37. Zhu MM, Qian YN, Zhu W, et al. Protective effects of ketamine on allergen-induced airway inflammatory injure and high airway reactivity in asthma: experiment with rats. Zhonghua Yi Xue Za Zhi. 2007;87: 1308-1313.

38. Zhu MM, Zhou QH, Zhu MH, et al. Effects of nebulized ketamine on allergen-induced airway hyperresponsiveness and inflammation in actively sensitized Brown-Norway rats. $J$ Inflamm (Lond). 2007; $4: 10$.

39. Sato T, Hirota K, Matsuki A, Zsigmond EK, Rabito SF. The role of the N-Methyl-D-Aspartic acid receptor in the relaxant effect of ketamine on tracheal smooth muscle. Anesth Analg. 1998;87:1383-1388.

40. Hirota K, Sato T, Rabito SF, Zsigmond EK, Matsuki A. Relaxant effect of ketamine and its isomers on histamine-induced contraction of tracheal smooth muscle. Br J Anaesth. 1996;76:266-270.

41. Heshmati F, Zeinali MB, Noroozinia H, Abbacivash R, Mahoori A. Use of ketamine in severe status asthmaticus in intensive care unit. Iran J Allergy Asthma Immunol. 2003;2:175-180.

42. Bourke DL, MAlit LA, Smith TC. Respiratory interactions of ketamine and morphine. Anesthesiology. 1987;66:153-156.

43. Hamza J, Ecoffey C, Gross JB. Ventilatory response to $\mathrm{CO} 2$ following intravenous ketamine in children. Anesthesiology. 1989;70: 422-425.

44. Shulman D, Beardsmore CS, Aronson HB, Godfrey S. The effect of ketamine on the functional residual capacity in young children. Anesthesiology. 1985;62:551-556.

45. Morris H, Wallach J. From PCP to MXE: a comprehensive review of the non-medical use of dissociative drugs. Drug Test Anal. 2014;6: 614-632.

46. Betts EK, Parkin CE. Use of ketamine in an asthmatic child: a case report. Anesth Analg. 1971;50(3):420-421.

47. Corssen G, Gutierrez J, Reves JG, Huber FC Jr. Ketamine in the anesthetic management of asthmatic patients. Anesth Analg Curr Res. 1972; 51:588-596.

48. Strube PJ, Hallam PL. Ketamine by continuous infusion in status asthmaticus. Anaesthesia. 1986;41:1017-1019.

49. Sarma VJ. Use of ketamine in acute severe asthma. Acta Anaesthesiol Scand. 1992;36:106-107.

50. Jahangir SM, Islam F, Chowdhury SN, Aziz L, Ghani MA. Ketamine infusion for postoperative analgesia: a prospective cohort study in asthmatics. Bangladesh Med Res Counc Bull. 1993;19:21-27.

51. Hemmingsen C, Nielsen PK, Odorico J. Ketamine in the treatment of bronchospasm during mechanical ventilation. Am J Emerg Med. 1994; 12:417-420.

52. Youssef-Ahmed MZ, Silver P, Nimkoff L, Sagy M. Continuous infusion of ketamine in mechanically ventilated children with refractory bronchospasm. Intensive Care Med. 1996;22:972-976.

53. Jat KR, Azad C, Guglani V. Use of ketamine for refractory wheezing in an infant. Indian Pediatr. 2012;49:587-588.

54. Agrawal A, Shrivastava J. Intravenous ketamine for refractory bronchospasm precipitated by H1N1 infection. Front Pediatr. 2014;2:24.

55. Howton JC, Rose J, Duffy S, Zoltanski T, Levitt MA. Randomized, double-blind, placebo-controlled trial of intravenous ketamine in acute asthma. Ann Emerg Med. 1996;27:170-175.

56. Jat KR, Chawla D. Ketamine for management of acute exacerbations of asthma in children. Cochrane Database Syst Rev. 2012;11: CD009293.

57. Krauss B, Green SM. Procedural sedation and analgesia in children. Lancet. 2006;367:766-780.

58. Corssen G, Little SC, Tavakoli M. Ketamine and epilepsy. Anesthes Analg. 1974;53:319-335.

59. Jolly T, McLean HS. Use of ketamine during procedural sedation. J Infus Nurs. 2012;35:377-382.

60. Umunna BP, Tekwani K, Barounis D, Kettaneh N, Kulstad E. Ketamine for continuous sedation of mechanically ventilated patients. J Emerg Trauma Shock. 2015;8:11-15.

61. Watts K, Chavasse RJ. Leukotriene receptor antagonists in addition to usual care for acute asthma in adults and children. Cochrane Database Syst Rev. 2012;5:CD006100. 
62. Wathen JE, Roback MG, Mackenzie T, Bothner JP. Does midazolam alter the clinical effects of intravenous ketamine sedation in children? A double-blind, randomized, controlled emergency department trial. Ann Emerg Med. 2000;36(6):579-588.

63. Slikker W Jr, Zou X, Hotchkiss CE, et al. Ketamine-induced neuronal cell death in the perinatal rhesus monkey. Toxicol Sci. 2007;98(1): 145-158.

64. Jevtovic-Todorovic V, Hartman RE, Izumi Y, et al. Early exposure to common anesthetic agents causes widespread neurodegeneration in the developing rat brain and persistent learning deficits. J Neurosci. 2003; 23(3):876-882.

65. Mazoit JX, Roulleau P, Baujard C. Isoflurane-induced neuroapoptosis in the neonatal rhesus macaque brain: isoflurane or ischemia-reperfusion? Anesthesiology. 2010;113(5):1245. [author reply 1245-1246].

66. Ikonomidou C, Bosch F, Miksa M, et al. Blockade of NMDA receptors and apoptotic neurodegeneration in the developing brain. Science. 1999;283(5398):70-74.
67. Zou X, Patterson TA, Sadovova N, et al. Potential neurotoxicity of ketamine in the developing rat brain. Toxicol Sci. 2009;108:149-158.

68. Shi Q, Guo L, Patterson TA, et al. Gene expression profiling in the developing rat brain exposed to ketamine. Neuroscience. 2010;166: $852-863$.

69. Braun S, Gaza N, Werdehausen R, et al. Ketamine induces apoptosis via the mitochondrial pathway in human lymphocytes and neuronal cells. Br J Anaesth. 2010;105(3):347-354.

70. Morgan CJ, Riccelli M, Maitland CH, Curran HV. Long-term effects of ketamine: evidence for a persisting impairment of source memory in recreational users. Drug Alcohol Depend. 2004;75:301-308.

71. Ubogu EE, Sagar SM, Lerner AJ, Maddux BN, Suarez JI, Werz MA. Ketamine for refractory status epilepticus: a case of possible ketamineinduced neurotoxicity. Epilepsy Behav. 2003;4:70-75.
Therapeutics and Clinical Risk Management

\section{Publish your work in this journal}

Therapeutics and Clinical Risk Management is an international, peerreviewed journal of clinical therapeutics and risk management, focusing on concise rapid reporting of clinical studies in all therapeutic areas outcomes, safety, and programs for the effective, safe, and sustained use of medicines. This journal is indexed on PubMed Central, CAS,

\section{Dovepress}

EMBase, Scopus and the Elsevier Bibliographic databases. The manuscript management system is completely online and includes a very quick and fair peer-review system, which is all easy to use. Visit http://www.dovepress.com/testimonials.php to read real quotes from published authors.

Submit your manuscript here: http://www.dovepress.com/therapeutics-and-clinical-risk-management-journal 